\title{
An Analysis of the Conformity Level between the Importance Level and Program Performance at the Subject Teacher Forum
}

\author{
Prawidi Wisnu Subroto ${ }^{1}$, Sigit Raharjo ${ }^{2}$ \\ \{prawidi.wisnu.s@gmail.com ${ }^{1}$, sigitraharjo42@gmail.com ${ }^{2}$ \} \\ Universitas Muhammadiyah Tangerang, Jl. Perintis Kemerdekaan I/33 Cikokol, Kota Tangerang, \\ Banten, Indonesia ${ }^{1,2}$
}

\begin{abstract}
This present research aims at obtaining information about the conformity level between the levels of importance and performance of the teachers' professional development program at the Subject Teacher Forum based on teachers' perceptions. There are five research indicators, namely: program structure, administrator's readiness, teachers' needs, teachers' motivation and institutional support. The research subjects were junior high school Mathematics teachers. The data collection technique used a questionnaire with a Likert scale, consisting of five importance level points and five performance points. This research analysis used a quantitative descriptive approach. The results point out that there are three indicators whose conformity level is above average (> $81 \%$ ) and close to $100 \%$, namely program structure, teachers' needs and teachers' motivation. The conclusion is that the level of conformity between the level of importance and program performance tends to be good. However, this program is necessary to improve institutional support and administrator's readiness.
\end{abstract}

Keywords: program structure, administrator's readiness, teachers' needs, teachers' motivation, institutional support

\section{Introduction}

Teacher is the main element and has an important role in realizing the quality of education. Therefore, for becoming professional educators, teachers are required to increase their capacity continuously. There are several competencies must be obtained by teachers through their professional education, such as pedagogical competence, personality competence, social competence and professional competence [1]. However, the fact shows that the teachers' competence nationally still needs attention and improvement, especially in terms of pedagogic and professional abilities as it is reflected from the results of the Teacher's Competency Test which do not show conformity with teachers' performance in the working education field [2].

This phenomenon can also be seen from the results of the Junior High School Teachers' Competency Test in Tangerang that their scores of pedagogic and professional competency reach an average of 60.54 [3]. This score is in the sufficient category and can still be better improved. These problems give the impression that the serious efforts of Junior High School Mathematics teachers in Tangerang, which have very good potential in developing their competence as teachers, are generally still not optimal.

A peer collaborative process at the Subject Teacher Forum (STF) becomes as one of various efforts to foster and to develop the teaching profession in Indonesia [4]. STF is a communication forum for teachers who teach the same subjects in a district/city. Here, they 
can exchange experiences, have a consultation, are involved in educational trainings and seminars as well as explore ideas for solving problems in learning management.

Teachers' professional development through coaching and training programs has often been reviewed by previous researchers. Among others are Gokmenoglu \& Clark [5], ChienChin Chen [6], and Doherty [7]. These studies are more focused on revealing the extent to which teachers can achieve increased competence after participating in the program. Whereas this research focuses on uncovering the fundamental problems related to program implementation. Thus, this research finding can become as important information in improving the next STF activity program. The research problem is as follows: How is the conformity level between the level of importance and performance of the teacher professional development program at the STF? There are five indicators that are the focus of research, namely: program structure, administrator's readiness, teachers' needs, teachers' motivation and institutional support.

In line with the background and research problems mentioned above, the purpose of this research is generally to obtain information about the level of conformity between the level of importance and performance of the teachers' professional development program at the STF. Specifically, the purpose of this research is to gain information about the level of conformity between the level of importance and program performance viewed from the perspective of program structure, administrator's readiness, teachers' needs, teachers' motivation, and institutional support.

The Subject Teacher Forum (STF) is a forum for teacher cooperation to collaborate in learning through activities that are initiated, implemented and evaluated together. This activity is carried out periodically with programs designed based on teachers' needs and organized by STF administrators. The STF program is a teacher professional development program to improve pedagogical and professional competence. The curriculum implementation comprehensively can only be achieved by skillful teachers in subjects, pedagogical skills and learning management [8].

The structure of the Mathematics teacher professional development program at the Junior High School Mathematics STF in Tangerang comprises of training activities, seminars and sharing of experiences between peer teachers. There are eleven attributes of program structure indicators, namely: 1) ICT training for teachers; 2) question writing workshop; 3) classroom action research seminar; 4) simulation of learning models; 5) workshop for making props; 6) study of learning tools; 7) graduate competency standard exploring activities; 8) The activity of preparing the Final Semester outlines; 9) development of learning tools; 10) multimedia utilization activities; and 11) Olympic question making activities. For the program structure that has been compiled to be able to be implemented effectively and efficiently requires the administrator's readiness to provide good supporting resources.

The administrator's readiness determines the smoothness and effectiveness of the activities at the STF, including training activities, seminars and sharing of experiences between peer teachers. The in-service teacher training programs are conducted to link any program given to teachers who are already working in schools to update and to increase their knowledge, technical skills and so on [9]. Several factors that contribute to the effectiveness of in-service training are the administrator's role, teachers' attitudes, training needs and strategies for conducting in-service training [10]. In line with this opinion, Vaillant \& Manso argue that training institutions must have the leadership, authority, budget, personnel, infrastructure, and resources for learning preparation to reach state standards [11]. The administrator's readiness indicators comprise of five attributes, namely: 1) the suitability of programs and activity budgets; 2) the availability of media/activity aids; 3) the availability of materials/sources of 
activities; 4) the socialization of the activity program; and 5) the evaluation of the previous activity program. The teacher professional development program through training must take into account and facilitate teachers' needs to achieve the effectiveness of the program.

STF participants are teachers who have different backgrounds in teaching knowledge and experience, thus training activities need to accommodate their needs. STF administrators need to identify and to consider projected material activities needed by teachers. This is to accommodate previous teachers' experiences, both in terms of knowledge and skills so that they can be more creative and innovative. According to Stronge cited by Sutopo, that the aspect of professional development refers to the need for development and improvement of teachers's professionalism in carrying out their duties [12]. In addition, Kirkpatrick, James \& Kirkpatrick, and Wendy state that learning is to what degree participants acquire the intended knowledge, skills, and attitudes based on their participation in the learning activity [13]. Indicators of teachers' needs include four attributes, namely: 1) activity materials that can improve knowledge; 2) training that can improve skills 3) activities that can increase creativity; and 4) suitability of the activity material with the teachers' needs. By fulfilling the teachers' needs in training activities, teachers will be motivated to participate fully in activities.

Activities at STF are expected to be qualified and beneficial for teachers' knowledge and skills improvement. One of which is an activity that can solve specific problems faced by them. Trainees' characteristics, instructional satisfaction and organizational factors of perceived learning significantly influence the perceptions of trainees [14]. In Kirkpatrick's program evaluation theory, teachers's perceptions of training activities are included in the reaction level that raise several questions in order to find out participants' interest and feeling about the training benefits after spending their time and effort [15]. The training program is effective if the training process satisfies participants for they are motivated to learn and practice [16]. Teachers' motivation indicators consist of three attributes, namely: 1) suitability of the resource persons' expertise with the activity material; 2) suitability of activity material with program objectives; 3) teachers' motivation to participate in STF activities. Teacher motivation in the STF activities is also influenced by the institutional support.

Supervision and awarding for good achievement or performance are useful for teacher's career development. Besides, it will be able to foster teacher's motivation and commitment to continue to strive improving the quality in learning management to achieve the best student's learning outcomes. The higher the awarding continuously given for employees, it will have an impact on increasing performance [17]. Rewards and recognition for the work accomplished by the leadership as motivation allows employees to continue working for the institution so that they are motivated to improve their performance [18]. Accordingly, if employees see the benefits of training and development programs such as incentives or promotions, they will be motivated and job satisfaction can be achieved, which in turn can lead to the increased performance and productivity [19]. Indicators of institutional support include two attributes, namely: 1) teacher's supervision of STF activities; 2) an award/recognition of teacher's performance.

\section{Method}

The research subjects were junior high school Mathematics teachers. The respondents are 83 teachers as participants in the STF from the population are 251 teachers. This research data collection technique used an instrument of a close questionnaire sheet with a Likert scale. The Likert scale consists of five points to measure the level of importance $(1=$ very unimportant to 
5 = very important $)$ and performance reality ( 1 = very dissatisfied to $5=$ very satisfied) on each attribute. The questionnaire consisted of 25 attribute items identified based on five indicators of the Mathematics teacher professional development program at the STF. The instrument design before use was validated by using expert's justification. Instruments that are already valid were then tested to see its reliability by using the application of SPSS version 20 with the Croncbach Alpha coefficient.

Data analysis determined the value (category) of the conformity level between the level of importance and the level of satisfaction with the attribute performance. The value of the conformity level is a comparison between the scores of performance and importance level presented in a percentage. Sukardi and Cholidis in Anggraini, Deoranto \& Ikasari state that the criteria for the level of conformity between the level of importance and the level of satisfaction with performance are said to be good, if the percentage level of attribute conformity is at least equal to the average percentage and close to $100 \%$ of all attributes [20].

The research findings are presented in tables that include the description of the conformity level between perceived reality (performance) and what the teacher expects (level of importance) to the attributes of the teacher's professional development program at STF. The value of this level of conformity will be used in determining priority handling of the factors that affect teacher's satisfaction. The formula used to measure the level of conformity is as below:

$$
\mathrm{Tk}=\mathrm{X} / \mathrm{Y} \times 100 \%
$$

$\mathrm{Tk}=$ The level of conformity between the level of importance and performance attributes.

$\mathrm{X}=$ The score of teachers' perceptions regarding performance attributes.

$\mathrm{Y}=$ The score of teachers' expectations regarding the importance level of the attributes.

\section{Results and Discussion}

The average level of conformity between importance and performance program is $81 \%$. This percentage is the criterion for determining the level of conformity of program attributes and indicators, as shown in table 1 as follows.

Table 1. Level of Conformity between Level of Importance and Performance Program

\begin{tabular}{lcccc}
\hline \multicolumn{1}{c}{ Indicators } & $\begin{array}{c}\text { Average of } \\
\text { Importance }\end{array}$ & $\begin{array}{c}\text { Average of } \\
\text { Performance }\end{array}$ & $\begin{array}{c}\text { Conformity } \\
\text { Level }\end{array}$ & $\begin{array}{c}\text { Criteria } \\
(>81 \%)\end{array}$ \\
\hline Program Structure & 4,23 & 3,50 & $83 \%$ & Good \\
\hline $\begin{array}{l}\text { Administrator's } \\
\text { Readiness }\end{array}$ & 4,30 & 3,45 & $80 \%$ & Poor \\
\hline Teachers' Needs & 4,16 & 3,46 & $83 \%$ & Good \\
\hline Teachers' Motivation & 4,16 & 3,53 & $85 \%$ & Good \\
\hline Institutional Support & 4,23 & 3,21 & $76 \%$ & Poor \\
\hline Average & 4,21 & 3,43 & $81 \%$ & \\
\hline
\end{tabular}

Table 1 above points out that none of the five indicators is $100 \%$ in accordance with the level of importance (expectations) of the teacher. However, there are three indicators whose conformity level is above average $(>81 \%$ ) and close to $100 \%$ or relatively in line with 
teacher's expectations, namely program structure (83\%), teachers' needs $(83 \%)$, and teachers' motivation $(85 \%)$. Meanwhile, indicators with a low level of conformity (below the average) are indicators of institutional support $(76 \%)$ and administrator's readiness $(80 \%)$. This indicates that the expectations of Mathematics teachers regarding the teacher professional development program at STF, which are described in all the attributes of the five indicators, are generally still below the reality accepted by teachers. In other words, the performance attributes of the five indicators still do not meet conformity of $100 \%$ between the level of importance and performance.

\subsection{The level of Conformity of Program Structure Indicator}

In an effort to achieve the objectives of the junior high school mathematics teacher professional development program at the STF in Tangerang, learning activities and work practices are designed consisting of Information and Communication Technology (ICT) training activities, question writing workshops, Classroom Action Research (CAR) seminars, simulations of learning models, and workshops for making props. Furthermore, work practices comprise of the exam subject matter analysis based on Graduate Competency Standards (GCS), preparation of Final Semester Examination outlines, development of learning tools, utilization of multimedia, and making Olympic questions. The level of conformity of the program structure is shown in table 2 below.

Table 2. Analysis of the Level of Conformity of Program Structure Indicator

\begin{tabular}{lcccc}
\hline \multicolumn{1}{c}{ Attributes } & $\begin{array}{c}\text { Average of } \\
\text { Importance }\end{array}$ & $\begin{array}{c}\text { Average of } \\
\text { Performance }\end{array}$ & $\begin{array}{c}\text { Conformity } \\
\text { Level }\end{array}$ & $\begin{array}{c}\text { Criteria } \\
(>81 \%)\end{array}$ \\
\hline $\begin{array}{l}\text { Information and } \\
\begin{array}{l}\text { Communication } \\
\text { Technology (ICT) } \\
\text { Training Activities }\end{array}\end{array}$ & 4,23 & 3,60 & $85 \%$ & Good \\
\hline $\begin{array}{l}\text { Question Writing } \\
\text { Workshops }\end{array}$ & 4,23 & 3,58 & $85 \%$ & Good \\
\hline $\begin{array}{l}\text { Classroom Action } \\
\text { Research (CAR) Seminars }\end{array}$ & 4,18 & 3,40 & $81 \%$ & Good \\
\hline $\begin{array}{l}\text { Simulations of Learning } \\
\text { Models }\end{array}$ & 4,23 & 3,30 & $78 \%$ & Poor \\
\hline $\begin{array}{l}\text { Workshops for Making } \\
\text { Props }\end{array}$ & 4,33 & 3,53 & $82 \%$ & Good \\
\hline $\begin{array}{l}\text { Analysis of Exam } \\
\text { Subject Matter }\end{array}$ & 4,23 & 3,43 & $81 \%$ & Good \\
\hline $\begin{array}{l}\text { Analysis of Graduate } \\
\text { Competency Standards } \\
\text { (GCS) of National Exam }\end{array}$ & 4,33 & 3,73 & $86 \%$ & Good \\
\hline $\begin{array}{l}\text { Preparation of Final } \\
\text { Semester Examination } \\
\text { Outlines }\end{array}$ & 4,43 & 3,80 & $86 \%$ & Good \\
\hline $\begin{array}{l}\text { Development of Learning } \\
\text { Tools }\end{array}$ & 4,18 & 3,50 & Good \\
\hline
\end{tabular}




\begin{tabular}{lcccc}
\hline Utilization of Multimedia & 4,20 & 3,45 & $82 \%$ & Good \\
\hline $\begin{array}{l}\text { Making Olympic } \\
\text { Questions (HOTS } \\
\text { Level) }\end{array}$ & 4,03 & 3,18 & $79 \%$ & Poor \\
\hline \multicolumn{1}{c}{ Average } & 4,23 & 3,50 & $83 \%$ & Good \\
\hline
\end{tabular}

Table 2 shows the average of percentage level of program structure indicator conformity of $83 \%$, this is higher than the average level of conformity of the overall attributes of the five program indicators, which is $81 \%$ (see table 1). This means that the level of performance of the attributes on the aspects of program objectives is generally in a good category or is in accordance with teacher's expectations at the level of $83 \%$.

Meanwhile, the attribute that has the lowest percentage level of conformity is the Simulation of Learning Models (78\%) followed by the attribute of the Olympic questionmaking activity (79\%). The percentage of these two attributes is less than $81 \%$ or lower than the average percentage of the level of conformity of the overall program indicator attributes. This shows that the level of performance of these two attributes is not in accordance with teachers' expectations, so that in the future program administrator need to consider the resource factors. The attributes that have the highest percentage level of conformity are GCS analysis activity (86\%) and preparation of Final Semester Examination (UAS) outlines (86\%). These two attributes have a level of conformity above the average, so that it is good and relatively close to $100 \%$ conformity for the level of importance and performance.

Analysis of the research results on program structure indicators shows that the teacher considers the attributes contained in the program structure of the STF activities have a high level of importance (high importance). The assumption is that the teacher thinks that activity program can improve knowledge and develop skills. This is in line with the proposition of Tanang, Abu \& Mukhtar on the importance of a teacher who has strong competence in subjects, pedagogical skills and an understanding about learning management, so that to improve students' performance and contribute to strengthen teachers in implementing the entire curriculum [21].

The structure of the Mathematics teacher professional development program at the STF in Tangerang is achieved by collaborating between peer teachers and presenting expert resource persons, through experience sharing, trainings, workshops and seminars. Teacher's professional development is influenced by positive school culture, cooperation between teachers and cooperation between teachers and external resource persons [22]. Although the level of importance and performance of the program structure attributes generally have a good level of conformity, it is necessary to improve the program for simulating learning models and making HOTS level questions.

\subsection{The level of Conformity of Administrator's Readiness Indicator}

The administrator's readiness for implementing junior high school Mathematics teachers' professional development programs at STF in Tangerang includes attributes of the conformity of program and activity budgets, the availability of media/activity aids, the availability of activity materials/sources, the socialization of activity programs and the evaluation of previous activity programs. The level of conformity of the administrator's readiness indicators is shown in the following table 3. 
Table 3. Analysis of the Level of Conformity of Administrator's Readiness Indicator

\begin{tabular}{|c|c|c|c|c|}
\hline Attributes & $\begin{array}{l}\text { Average of } \\
\text { Importance }\end{array}$ & $\begin{array}{c}\text { Average of } \\
\text { Performance }\end{array}$ & $\begin{array}{l}\text { Conformity } \\
\text { Level }\end{array}$ & $\begin{array}{l}\text { Criteria } \\
(>81 \%)\end{array}$ \\
\hline $\begin{array}{l}\text { The } \\
\text { Conformity } \\
\text { of Program } \\
\text { and } \\
\text { Activity } \\
\text { Budgets }\end{array}$ & 4,28 & 3,43 & $80 \%$ & Poor \\
\hline $\begin{array}{l}\text { The } \\
\text { Availability of } \\
\text { Media/Activity } \\
\text { Aids }\end{array}$ & 4,40 & 3,05 & $69 \%$ & Poor \\
\hline $\begin{array}{l}\text { The Availability } \\
\text { of Activity } \\
\text { Materials/Sources }\end{array}$ & 4,33 & 3,68 & $85 \%$ & Poor \\
\hline $\begin{array}{l}\text { The Socialization } \\
\text { of Activity } \\
\text { Programs }\end{array}$ & 4,33 & 3,50 & $81 \%$ & Good \\
\hline $\begin{array}{l}\text { The Evaluation } \\
\text { of Previous } \\
\text { Activity } \\
\text { Programs }\end{array}$ & 4,18 & 3,58 & $86 \%$ & Good \\
\hline Average & 4,30 & 3,45 & $80 \%$ & Poor \\
\hline
\end{tabular}

Table 3 defines that the percentage level of conformity for the administrator's readiness indicator is $80 \%$, lower than the average percentage level of conformity for the overall program indicator attributes $(80 \%<81 \%)$ or in the poor category This means that the level of performance of the attributes on the indicator of administrator's readiness is relatively less in line with teacher's expectations.

Meanwhile, the attribute that has the lowest percentage level of conformity is the availability of media/activity aids at the STF (69\%) followed by the attributes of program conformity and activity budget. The percentage of these two attributes is less than $81 \%$ or is lower than the average percentage of the level of conformity of all program indicator attributes. This shows that the level of performance of these two attributes is not in line with the teachers' expectations, so that in the future, program administrators need to consider factors of supporting resources in the form of media/tools and an adequate activity budget for improvement.

The attribute that has the highest percentage level of conformity is the evaluation of the previous activity program (86\%) followed by the availability of materials/activity sources $(85 \%)$. These two attributes have a level of conformity above the average, so it is good and relatively close to $100 \%$ between the level of importance and performance.

The analysis of the research results for STF administrator's readiness indicator show that the attributes of administrator's readiness are considered by teachers to have a high level of importance (high importance), but in general the performance attributes are considered low (low performance). This is due to the lack of availability of program support capacity, such as media/activity aids and conformity between programs and budgets. The lack of availability of the carrying capacity of this program does not meet the factor of program effectiveness. 
The administrator's role, teacher's attitudes, training needs and strategies for conducting training are factors contributing to the effectiveness of in-service training [23]. Concerning to the low readiness performance of STF administrators, it is necessary to increase the provision of training needs, especially for media/tools and appropriate activity budgets.

To become profesionals, teachers should be equipped by policies support, morals, infrastructures, and funds [24]. In the policy context, the government needs to make policies on school performance standards in relation to community-based teacher professional development. Thus, the principal and officials of the Education Office will have a real interest in improving teacher's professionalism, thus encouraging good cooperation for the management of STF activities. Good cooperation related to time management, administration, budget, facilities and strategies in carrying out activities.

\subsection{The level of Conformity of Teachers' Needs Indicator}

The indicator of teachers' needs in implementing junior high school Mathematics teacher's professional development programs at STF in Tangerang include the attributes of activity materials that can improve knowledge, training that can improve skills, activities that can increase creativity, and the suitability of activity materials with teachers' needs. The level of conformity of the teachers' needs indicator is described in table 4 below.

Table 4. Analysis of the Level of Conformity of Teachers' Needs

\begin{tabular}{lcccc}
\hline \multicolumn{1}{c}{ Attributes } & $\begin{array}{c}\text { Average of } \\
\text { Importance }\end{array}$ & $\begin{array}{c}\text { Average of } \\
\text { Performance }\end{array}$ & $\begin{array}{c}\text { Conformity } \\
\text { Level }\end{array}$ & $\begin{array}{c}\text { Criteria } \\
(>81 \%)\end{array}$ \\
\hline $\begin{array}{l}\text { Activity Materials That Can } \\
\text { Improve Knowledge }\end{array}$ & 4,08 & 3,65 & $90 \%$ & Good \\
\hline $\begin{array}{l}\text { Training That Can Improve } \\
\text { Skills }\end{array}$ & 4,15 & 3,40 & $82 \%$ & Good \\
\hline $\begin{array}{l}\text { Activities That Can Increase } \\
\text { Creativity }\end{array}$ & 4,20 & 3,25 & $77 \%$ & Poor \\
\hline $\begin{array}{l}\text { The Suitability Of } \\
\text { Activity Materials } \\
\begin{array}{l}\text { With Teachers' } \\
\text { Needs }\end{array}\end{array}$ & 4,20 & 3,53 & $84 \%$ & Good \\
\hline \multicolumn{1}{c}{ Average } & 4,16 & 3,46 & $83 \%$ & Good \\
\hline
\end{tabular}

Table 4 presents the percentage level of conformity for the indicator of teachers' needs is $83 \%$, higher than the percentage of the average level of conformity of the overall program indicator attributes $(83 \%>81 \%)$. This means that teachers' perceptions of the performance of the attributes for the indicator of teachers' needs are in line with teachers' expectations at the level of $83 \%$.

Meanwhile, the attribute that has the lowest percentage level of conformity and is below the average is the existence of activities that can increase creativity $(77 \%)$ or less in line with teachers' expectations. While the attribute that has the highest percentage level of conformity, above the average and close to $100 \%$, is the activity material that can improve knowledge $(90 \%)$. The performance of this attribute is already in line with the level of importance at the level of $90 \%$. 
Analysis of the research results on teachers' needs indicator, when viewed from the level of conformity between the level of importance and performance of the attributes of teachers' needs in general is in the good category. However, on the other hand, the performance of the program implementation activities is considered to be still not encouraging creativity. In this case, it is necessary to innovate activity models in order to provide inspiration to encourage creativity. So that not only the activity material meets the teachers' needs, but also for the performance of the activity. The STF activity model needs innovation in order to encourage teacher's creativity to answer the real challenges faced in managing the learning.

The performance of teacher's professional development program activities that cannot meet their needs is not in line with Strong's statement cited by Sutopo, that developing teacher professionalism must be based on the real teachers' needs in doing their work [25]. Therefore, in planning the next program activities, STF administrators need to conduct a preliminary survey on real problems related to learning activities faced by teachers.

\subsection{The level of Conformity of Teachers' Motivation Indicator}

The indicator of teachers' motivation in implementing junior high school Mathematics teacher professional development programs at STF in Tangerang comprises attributes of the conformity of resource persons' expertise with activity material, the conformity of activity material with program objectives and the existence of teachers' motivation to participate in STF activities. The level of conformity of the teachers' motivation indicator is described in table 5 as follow.

Table 5. Analysis of the Level of Conformity of Teachers' Motivation

\begin{tabular}{lcccc}
\hline Attributes & $\begin{array}{c}\text { Average of } \\
\text { Importance }\end{array}$ & $\begin{array}{c}\text { Average of } \\
\text { Performance }\end{array}$ & $\begin{array}{c}\text { Conformity } \\
\text { Level }\end{array}$ & $\begin{array}{c}\text { Criteria } \\
(>81 \%)\end{array}$ \\
\hline $\begin{array}{l}\text { The Conformity of } \\
\text { Resource Persons' } \\
\text { Expertise with } \\
\text { Activity Material }\end{array}$ & 4,28 & 3,75 & $88 \%$ & Good \\
\hline $\begin{array}{l}\text { The Conformity of } \\
\text { Activity Material } \\
\text { with Program }\end{array}$ & 4,08 & 3,53 & $87 \%$ & Good \\
Objectives & 4,13 & 3,33 & $81 \%$ & Good \\
\hline $\begin{array}{l}\text { The Teachers } \\
\text { Motivation To } \\
\begin{array}{l}\text { Participate in STF } \\
\text { Activities }\end{array}\end{array}$ & & & & Good \\
\hline \multicolumn{1}{c}{ Average } & 4,16 & 3,53 & $85 \%$ & \\
\hline
\end{tabular}

Table 5 informs the percentage level of conformity of the teachers' motivation indicator is $85 \%$, higher than the average percentage of the overall conformity level of the attributes of the five program indicators $(85 \%>81 \%)$ and close to $100 \%$. This means that teachers' perceptions of the performance of the attributes of the motivational indicators are in line with teachers' expectations at the level of $85 \%$.

Meanwhile, the attribute that has the lowest percentage level of conformity is the teachers' motivation to participate in STF activities (81\%), but it is still in the good category. The 
percentage level of the conformity of this attribute has a very small difference in numbers with the criteria. This means that the performance of teachers' motivation indicator attributes is still in line with the level of program importance or in accordance with teachers' expectations. Meanwhile, the attribute that has the highest percentage level of conformity is the conformity of the resource persons' expertise with the activity material (88\%). Therefore, the suitability of the resource persons with the activity material is considered in accordance with the teachers' expectations at a high level.

Analysis of the research results on teachers' motivation indicator is in the good category, this shows that the teachers assess the teacher's professional development program at the STF as beneficial for them. There is conformity between the resource persons' expertise with activity materials and activity materials with program objectives. Thus, they have high motivation in participating in the STF activities. This condition is in line with Luong's proposition which can be interpreted, that from the reactions of the trainees it can be seen whether they like participating in the training and whether they feel they have benefited after spending their time and efforts [26].

In general, the level of conformity between the importance and the performance of the attributes of the teachers' motivation indicator is good. The conformity of the resource persons' expertise with the activity material was assessed by the teacher as good. Therefore, good performance as an indicator of teachers' motivation needs to be maintained in the implementation of further STF activity program.

\subsection{The level of Conformity of Institutional Support Indicator}

The indicator of institutional support for the implementation of the junior high school Mathematics teacher's professional development program at STF in Tangerang consists of the attributes of the teacher's supervision in STF activities and the existence of rewards/recognition of teacher's performance. The level of conformity of the institutional support indicator can be seen in table 6 below.

Table 6. Analysis of the Level of Conformity of Institutional Support

\begin{tabular}{lcccc}
\hline \multicolumn{1}{c}{ Attributes } & $\begin{array}{c}\text { Average of } \\
\text { Importance }\end{array}$ & $\begin{array}{c}\text { Average of } \\
\text { Performance }\end{array}$ & $\begin{array}{c}\text { Conformity } \\
\text { Level }\end{array}$ & $\begin{array}{c}\text { Criteria } \\
(>81 \%)\end{array}$ \\
\hline $\begin{array}{l}\text { The Teacher's Supervision } \\
\text { in MGMP Activities }\end{array}$ & 4,05 & 3,38 & $83 \%$ & Good \\
\hline $\begin{array}{l}\text { The Existence of } \\
\begin{array}{l}\text { Rewards/Recognition of } \\
\text { Teacher's Performance }\end{array}\end{array}$ & 4,40 & 3,05 & $69 \%$ & Poor \\
\hline \multicolumn{1}{c}{ Average } & 4,23 & 3,21 & $76 \%$ & Poor \\
\hline
\end{tabular}

Table 6 points out that the attribute that is relatively in line with teachers' expectations is the teachers' supervision in STF activities with a percentage of $83 \%$. The level of conformity of this attribute is higher than the average percentage of the level of conformity of all program indicators $(83 \%>81 \%)$. While one other attribute, namely the existence of rewards/recognition of teacher's performance with a conformity level of $69 \%$ indicates that it is not in line with teachers' expectations. The percentage of the conformity level of this attribute is lower than the average percentage of the level of conformity of all program indicators $(69 \%<81 \%)$. 
While in general, the percentage level of conformity for the institutional support indicator is $76 \%$, this is lower than the average percentage level of conformity for the overall program indicators $(76 \%<81 \%)$. The low level of conformity between the level of importance and the performance of the institutional support indicator is caused by the low rewards or recognition of school institutions for teachers' performance.

The analysis of research results that shows the low support from school institutions concerning to rewards or recognition of teachers' performance in STF activities needs serious attention from interested parties. In this case, the Principal and School Supervisors need to increase their support not only for supervision, but also giving awards or recognition to teachers' performance. As the results of research conducted by Prabu \& Wijayanti, the higher the continuous awarding of employees will have an impact on increasing performance [27]. Likewise, the research results of Wahab, Hussain, Zadeh \& Shah, that giving incentives or promotions will motivate employees, so that job satisfaction can be achieved, which in turn can lead to the increased performance and productivity [28].

Rewards or recognition of good teacher's performance needs to be as a main priority for STF administrators for improvement in the implementation of teacher's professional development programs at the next STF. STF administrators need to collaborate effectively with interested parties on teachers' performance.

\section{Conclusion}

Conclusively, the research results point out that the level of conformity between the level of importance and performance of the teachers' professional development program at STF is generally in the good category and is beneficial for teachers and school institutions. The level of conformity between the level of importance and program performance viewed from the program structure of the STF is generally in the good category, tends to be effective, in line with the concept to strengthen subject competence, pedagogic skills, and teachers' understanding of learning management. While viewed from the readiness of the STF administrators is generally in the poor category. This includes the conformity of providing budget and program, media/tools and materials/sources for learning activities, as well as conducting program socialization and evaluation of previous programs. Therefore, it is necessary to improve the readiness in managing the development of STF activity programs in order to encourage the active role of teachers in order to achieve the effectiveness of the activities implementation.

The level of conformity between the level of importance and program performance in terms of the perspective of teachers' needs is generally in the good category. However, it has not been able to increase creativity to answer current learning problems faced by teachers. Therefore, STF administrators need to improve the planning of activity programs by identifying and considering projections of activity material that are needed by teachers, to accommodate previous teachers' experiences, both in terms of knowledge and skills, so that teachers can be more creative and innovative. Likewise with respect to teachers' motivation is generally in the good category, has meaning (value) for improving work professionalism as a teacher. Teachers like, feel happy and feel that they benefit from these activities so that motivation arises in the teacher to be actively involved.

While the level of conformity between the level of importance and program performance of the perspective on institutional support (schools) is generally in the poor category. The effectiveness of the principal's involvement needs to be improved, such as supervision, the ease with which teachers participate in STF activities, and rewards or recognition of teachers' 
performance in the STF activity process and after teachers return to work at school. The ineffective support of this school institution can be suspected as the cause of some schools whose teachers do not actively participate in the STF activities. For this problem, further research is needed.

\section{References}

[1] Undang-Undang Republik Indonesia Nomor 14 Tahun 2005 tentang Guru dan Dosen, Pasal 1, Ayat 1.

[2] Jumadi, Prasetyo, Zuhdan, K., Wilujeng, Insih, Pemetaan Kompetensi Pedagogik, Profesional, Kepribadian dan Sosial Guru Fisika SMA/MA di Daerah Istimewa Yogyakarta, available at: https://eprints.uny.ac.id/23362/Ilap.pdf, (2013)

[3] Kemendikbud, Neraca Pendidikan Daerah-NPD, Data UKG, available at: https://npd.kemdikbud.go.id/?appid=ukg, (2019)

[4] Kemendiknas, Rambu-Rambu Pengembangan Kegiatan KKG dan MGMP. Jakarta :

Kemetrian Pendidikan Nasional (2010).

[5] Gokmenoglu \& Clark, Teachers' evaluation of professional development in support of national reforms,

https://www.researchgate.net/publication/288841437_Teachers'_evaluation_of_professional_devel opment_in_support_of_national_reforms (2015)

[6] Chien-Chin Chen (2018) berjudul Facilitation of Teachers' Professional Development through Principals' Instructional Supervision and Teachers' Knowledge-Management Behaviors, https://www.semanticscholar.org/paper/Facilitation-of-Teachers\%E2\%80\%99-ProfessionalDevelopment-Chen/1a9ece29a089fde542d5c5e62a0be46cfd2c47b2 (2018)

[7] Doherty I., Evaluating the Impact of Professional Development on Teaching Practice: Research Findings and Future Research Directions https://files.eric.ed.gov/fulltext/ED527691.pdf (2011)

[8] Tanang, H., Abu, B., Teacher Professionalism and Professional Development Practices in South Sulawesi, Indonesia, available at: https://files.eric.ed.gov/fulltext/EJ1157754.pdf, (2014)

[9] Madani, Roghayeh R., Poumohammadi, M., An Investigation of the Effectiveness of English Teachers' In-Service Training on Iranian Third Grade High School Students' English Achievement, available at: https://www.jallr.com/index.php/JALLR/article/download/483/pdf483, (2017)

[10] Omar, C., Zulkifli, M. C., The Need for In-Service Training for Teachers and It's Effectiveness In School, available at: https://www.ijier.net/index.php/ijier/article/Download/261/181/, (2014)

[11] Vallaint, D., Manso, J., Teacher Education Programmes Learning From Worldwide Inspiring Experiences, available at: http://www.denisevaillant.com/wp-content/uploads/2018/08/ JOSPOE_1_8.pdf, (2018)

[12] Sutopo (2013). Dampak Sertifikasi Guru SMK terhadap Kinerja Guru. UNY, p. 46, available at: https://eprints.uny.ac.id/ 22860/1/artikel_ST.pdf, (2013)

[13] Kirkpatrick, D., Kirkpatrick, W., An Introduction to the New World Kirkpatrick Model, available at: http://www.kirkpatrickpartners.com/Portals/0/Resources/White\%20Papers/Introduction\%20to\% 20the \%20Kirkpatrick\%20New\%20World\%20Model.pdf, (2019)

[14] Lim, Doo, H., Moris, Michael, L., Influence of Trainee Characteristics, Instructional Satisfaction, and Organizational Climate on Perceived Learning and Training Transfer, available at: https://onlinelibrary.wiley.com/doi/epdf/ 10.1002/hrdq.1162, (2009)

[15] Kirkpatrick, D., Kirkpatrick, W., An Introduction to the New World Kirkpatrick Model, available at: http://www.kirkpatrickpartners.com/Portals/0/Resources/White\%20Papers/Introduction\%20to\% 20the \%20Kirkpatrick\%20New\%20World\%20Model.pdf, (2019)

[16] Badu, QS. The implementation of Kirkpatrick's evaluation model in the learning of Initial Value and Bondary Condition Problems. International Journal of Learning \& Development. 2013; Vol. 3, No. 5: p. 6. 
[17] Prabu, Aldila, S., Wijayanti, Dewie, T., Pengaruh Penghargaan dan Motivasi terhadap Kinerja Karyawan, available at: file:///C:/Users/PC/Downloads/17144-50640-3-PB.pdf (2016)

[18] Ndungu, Daniel, N., The Effects of Rewards and Recognition on Employee Performance in Public Educational Institutions: A Case of Kenyatta University, Kenya, available at: file:///C:/Users/PC/Downloads/2183-1-2164-1-10-20170409\%20(1).pdf, (2017)

[19] Wahab, Abdul, Rollah, S., Hussain, A., Zadeh, Abdollah, A., Shah, Ali, F., \& Hussain, J., Employees' Perception and Motivation towards Training and Development Programmes in Health Sector of Pakistan: A Case Study of Khyber Pakhtunkhwa, available at: https://pdfs.semanticscholar.org/5e0e/5ea40aa972944a916425210d38da4f2afb1a.pdf, (2014)

[20] Anggraeni, D. L., Deoranto, P., Ikasari, M. D., Analisis Persepsi Konsumen Menggunakan Metode Importance Performance Analysis dan Customer Satisfaction Index, available at: https://industria.ub.ac.id/index.php/industri/article/view/179, (2015)

[21] Tanang, H., Djajadi, M., Abu, B., Mokhtar, M., Challenges of Teaching Professionalism Development: A Case Study in Makassar, Indonesia, available at: https://media.neliti.com/media/publications/71474-EN-challenges-for-teachers-in developingth.pdf, (2014)

[22] Postholm, May B., Teachers' Professional Development: A Theoretical Revie, available at:. https://www.researchgate.netpublication/263253581, (2012)

[23] Ndungu, Daniel, N., The Effects of Rewards and Recognition on Employee Performance in Public Educational Institutions: A Case of Kenyatta University, Kenya, available at: file://C:/Users/PC/Downloads/2183-1-2164-1-10-20170409\%20(1).pdf, (2017)

[24] Tanang, H., Abu, B., Teacher Professionalism and Professional Development Practices in South Sulawesi, Indonesia, available at: https://files.eric.ed.gov/fulltext/EJ1157754.pdf, (2014)

[25] Sutopo, Dampak Sertifikasi Guru SMK terhadap Kinerja Guru. UNY, p. 46., available at: https://eprints.uny.ac.id/22860/1/artikel_ST.pdf, (2013)

[26] Luong, Ha Ngoc, L., Factors Influence Training Effectiveness in Micro and Small Enterprises, available at: https://www.theseus.fi/handle/10024/96615, (2015)

[27] Prabu, Aldila, S., Wijayanti, Dewie, T., Pengaruh Penghargaan dan Motivasi terhadap Kinerja Karyawan, available at: file:///C:/Users/PC/Downloads/17144-50640-3-PB.pdf, (2016)

[28] Wahab, Abdul, Rollah, S., Hussain, A., Zadeh, Abdollah, A., Shah, Ali, F., \& Hussain, J., Employees' Perception and Motivation towards Training and Development Programmes in Health Sector of Pakistan: A Case Study of Khyber Pakhtunkhwa, available at: https://pdfs.semanticscholar.org/5e0e/5ea40aa972944a916425210d38da4f2afb1a.pdf, (2014) 